\title{
磺酸基团功能化的碳-硅介孔复合材料的制备及其 在生物柴油绿色合成中的应用
}

\author{
方林, 张坤, 李晓红, 吴海虹, 吴 鹏* \\ 华东师范大学化学系, 上海市绿色化学与化工过程绿色化重点实验室, 上海200062
}

\begin{abstract}
摘要: 利用化学浸渍法将蔗糖负载到 SBA-15 介孔材料孔道内部, 高温炭化形成的多聚苯环经发烟硫酸气相磺化处理后, 得到 磺酸基团功能化的新型碳-硅介孔复合材料. 发烟硫酸气相磺化处理是该材料合成的关键步骤. X 射线衍射、扫描电镜和氮气 吸附结果表明, 碳-硅介孔复合材料经磺酸化处理保持了高度有序的介孔结构. 热重、傅里叶变换的红外光谱及吡啶吸附红外光 谱结果证明, 磺酸功能基团成功的嫁接于碳-硅介孔复合材料孔道的内表面, 反应活性中心为 Brønsted 酸, 酸密度在 $0.09 \sim 0.70$ $\mathrm{mmol} / \mathrm{g}$ 可以有效调变. 当碳负载量为 $35 \%$ 时, 该复合材料在生物柴油的绿色合成中显示出最优的催化性能, 且可重复使用 3 次以上.
\end{abstract}

关键词: 固体酸; 碳材料; 磺酸功能基; 生物柴油; 介孔材料

中图分类号: O643 文献标识码: A

收稿日期: 2011-08-10. 接受日期: 2011-09-19.

*通讯联系人. 电话/传真: (021)62332292; 电子信箱: pwu@chem.ecnu.edu.cn

基金来源：国家自然科学基金 (20925310,21003050).

本文的英文电子版(国际版)由Elsevier出版社在ScienceDirect上出版(http://www.sciencedirect.com/science/journal/18722067).

\section{Preparation of a Carbon-Silica Mesoporous Composite Functionalized with Sulfonic Acid Groups and Its Application to the Production of Biodiesel}

\author{
FANG Lin, ZHANG Kun, LI Xiaohong, WU Haihong, WU Peng* \\ Shanghai Key Laboratory of Green Chemistry and Chemical Processes, Department of Chemistry, East China Normal University, \\ Shanghai 200062, China
}

\begin{abstract}
A carbon-mesoporous silica (CS) composite functionalized with sulfonic acid $\left(-\mathrm{SO}_{3} \mathrm{H}\right)$ groups was prepared by controlled carbonization of sucrose impregnated in SBA-15 mesoporous silica and its subsequent sulfonation. The moderate vapor phase sulfonation of the CS composite with fuming sulfuric acid $\left(\mathrm{H}_{2} \mathrm{SO}_{4} \cdot 20 \% \mathrm{SO}_{3}\right)$ was the key step in preparing the strong acid solid material $\left(\mathrm{CS}-\mathrm{SO}_{3} \mathrm{H}\right)$. Structural analysis and reaction data revealed that sulfonic acid groups were successfully incorporated into the mesoporous CS composite, and the Brønsted acid site density was tunable from 0.09 to $0.70 \mathrm{mmol} / \mathrm{g}$ by tuning the carbon loading. The sample with $35 \mathrm{wt} \%$ carbon exhibited a remarkable catalytic activity for biodiesel production by the esterification of palmitic acid and the transesterification of soybean oil with methanol.
\end{abstract}

Key words: Solid acid; carbon; sulfonic acid group; biodiesel; mesoporous materials

Received 10 August 2011. Accepted 19 September 2011.

*Corresponding author.Tel/Fax: +86-21-62232292; E-mail: pwu@chem.ecnu.edu.cn

This work was supported by the National Natural Science Foundation of China (20925310 and 21003050).

English edition available online at Elsevier ScienceDirect (http://www.sciencedirect.com/science/journal/18722067).

The eco-friendly production of biodiesel will play an important role in meeting the requirements for a sustainable society $[1,2]$. The large scale synthesis of biodiesels has relied on homogeneous acid catalysts, such as $\mathrm{H}_{2} \mathrm{SO}_{4}, \mathrm{HF}$, and $\mathrm{H}_{3} \mathrm{PO}_{4}$, which are active in the esterification of fatty acids [3-5]. However, these require a special process of 
neutralization, in addition to requiring a costly and inefficient catalyst separation. Due to their facile separation and recycled use, solid acid catalysts, such as microporous zeolites, structured metallic complexes, amorphous silica-alumina, and heteropoly acids, are promising replacement catalysts [6-9]. However, the small pore size $(<2.0$ $\mathrm{nm})$ and low surface area of these catalysts have resulted in their very limited use in biodiesel synthesis.

The discovery of mesoporous materials with extremely high surface area (ca. $\left.1000 \mathrm{~m}^{2} / \mathrm{g}\right)$, large pore volume $(>1.0$ $\mathrm{cm}^{3} / \mathrm{g}$ ), and uniform nanosized pores $(>2.0 \mathrm{~nm}$ ) has opened up new opportunities for designing novel solid acid catalysts [10,11]. In the last decade, the preparation of mesoporous solid acid catalysts has focused on the functionalization and modification of silica-based and organosilica hybrid materials with trivalent aluminum cations and sulfonic acid groups [12-15]. The incorporation of Al into mesoporous silica can be realized by direct hydrothermal synthesis or post-synthesis, while $-\mathrm{SO}_{3} \mathrm{H}$ group functionalized mesoporous silicas are usually prepared from the oxidation with $\mathrm{H}_{2} \mathrm{O}_{2}$ of - $\mathrm{SH}$ groups post-grafted or directly incorporated onto the silica walls. However, the silica walls were functionalized only by a limited amount of $-\mathrm{SH}$ groups due to the hydrophobic nature of the silane agents. Furthermore, there is a need to avoid a possible $\mathrm{Si}-\mathrm{C}$ bond cleavage in the processes of direct synthesis and surfactant removal. Accordingly, the $-\mathrm{SO}_{3} \mathrm{H}$-functionalized mesoporous silica materials have relatively low $-\mathrm{SO}_{3} \mathrm{H}$ densities and low activity in practical acid-catalyzed reactions.

Other promising solid acid catalysts are carbon-based materials bearing sulfonic acid groups. Hara et al. [1,16] first demonstrated that cellulose-derived amorphous carbon bearing $-\mathrm{SO}_{3} \mathrm{H},-\mathrm{OH}$, and $-\mathrm{COOH}$ groups are highly active catalysts for the production of biodiesel, exhibiting a catalytic activity comparable with that of $\mathrm{H}_{2} \mathrm{SO}_{4}$. Even though its synthesis is very simple and efficient, this material had limited applications in acid-catalyzed reactions, due to the very low specific surface area $\left(<5 \mathrm{~m}^{2} / \mathrm{g}\right)$.

Recently, we reported the preparation of $-\mathrm{SO}_{3} \mathrm{H}$-functionalized FDU-type mesoporous polymers with large surface area (ca. $550 \mathrm{~m}^{2} / \mathrm{g}$ ) and pore volume (ca. $0.35 \mathrm{~cm}^{3} / \mathrm{g}$ ) by vapor phase sulfonation [17]. This kind of moderate sulfonation was performed by contacting the sample powder with the vapor from fuming sulfuric acid in a closed autoclave, which proved to be more effective than either the direct dipping of the carbon in concentrated or fuming $\mathrm{H}_{2} \mathrm{SO}_{4}$ or the treatment with pure $\mathrm{SO}_{3}$ gas. This strategy was also extended to synthesize a CMK-3 type solid acid catalyst [18], which showed remarkable catalytic performance in many reactions, such as liquid phase Beckmann rearrangement of cyclohexanone oxime and condensation of ethylene glycol with aldehydes.
A similar procedure was adopted by Hara and coworkers $[19,20]$ to prepare sulfonic functionalized solid acid catalysts using CMK-3 and amorphous carbon/mesoporous silica composites as supports, respectively. Using carbon/mesoporous silica directly as the support is simpler and more time-saving in comparison with the synthesis of pure carbon-based mesoporous materials by the replication of mesoporous silica with some complicated nanocasting methods.

Here, a carbon/mesoporous silica composite functionalized with sulfonic groups was synthesized by vapor phase sulfonation. We found that a moderate loading of sucrose (ca. $35 \mathrm{wt} \%$ ) was suitable for preparing the $-\mathrm{SO}_{3} \mathrm{H}$ functionalized composite catalyst, and it exhibited a most remarkable catalytic performance in esterification and transesterification involving large molecules. When the carbon loading was further increased in the mesopores of SBA-15, pore jamming occurred that significantly decreased the activity of the solid acid catalyst. The results are useful for the design of solid acid catalysts for reactions involving large molecules.

\section{Experimental}

\subsection{Chemicals and reagents}

All reagents were analytical grade and used as purchased without further purification. Tetraethyl orthosilicate (TEOS) and triblock copolymer surfactant poly(ethyleneoxide)poly(propyleneoxide)-poly(ethyl-eneoxide) (P123, MW $\approx$ 5800) were purchased from Sigma-Aldrich. Hydrochloric acid (37\%), sulfuric acid (98\%), $\mathrm{H}_{2} \mathrm{SO}_{4} \cdot 20 \% \mathrm{SO}_{3}$, sucrose, and methanol (>99.5\%) were from China National Medicines Corporation Ltd. Palmitic acid (95\%) was purchased from Alfa Aesar. The soybean oil (SBO, Fu Lin Men, China) was commercially available.

\subsection{Catalyst preparation}

\subsubsection{Preparation of carbon/carbon-silica composite}

Mesoporous SBA-15 was synthesized by following the conventional method using P123 and TEOS [11]. According to a defined weight ratio of carbon in the carbon-silica composite, a solution containing the desired amount of sucrose and $2 \mathrm{wt} \%$ concentrated $\mathrm{H}_{2} \mathrm{SO}_{4}$ was well mixed with $1.6 \mathrm{~g} \mathrm{SBA}-15$. The mixture was dried by evaporating the water at $423 \mathrm{~K}$ for $5 \mathrm{~h}$. This led to a primary dehydration and carbonization of the sucrose. The composite was subsequently evacuated at $673 \mathrm{~K}$ for $6 \mathrm{~h}$, which induced an incomplete carbonized pyrolysis, resulting in a dark brown solid composite (denoted C/CS). A series of samples with 
carbon loading of $5 \mathrm{wt} \%, 15 \mathrm{wt} \%, 25 \mathrm{wt} \%, 35 \mathrm{wt} \%$ and 45 wt $\%$ were obtained by varying the amount of impregnated sucrose in the range of $0.2-2.9 \mathrm{~g}$. For the samples with 35 $\mathrm{wt} \%$ and $45 \mathrm{wt} \%$ carbon loading, the procedures of sucrose impregnation and carbonization were repeated.

\subsubsection{Sulfonation of $\mathrm{C} / \mathrm{CS}$}

The C/CS ( $1 \mathrm{~g}$ ) was sulfonated in a closed container with $10 \mathrm{ml}$ concentrated $\mathrm{H}_{2} \mathrm{SO}_{4}$ or $\mathrm{H}_{2} \mathrm{SO}_{4} \cdot 20 \% \mathrm{SO}_{3}$ to form the sulfonic acid group functionalized solid acids (Fig. 1). After washing with hot deionized water $(>353 \mathrm{~K}$ ) to remove physically adsorbed species and filtration until sulphate ions were no longer detected by $\mathrm{BaSO}_{4}$ in the filtrate, the samples $\left(\mathrm{C} / \mathrm{CS}-\mathrm{SO}_{3} \mathrm{H}\right)$ were dried at $373 \mathrm{~K}$ overnight in air.

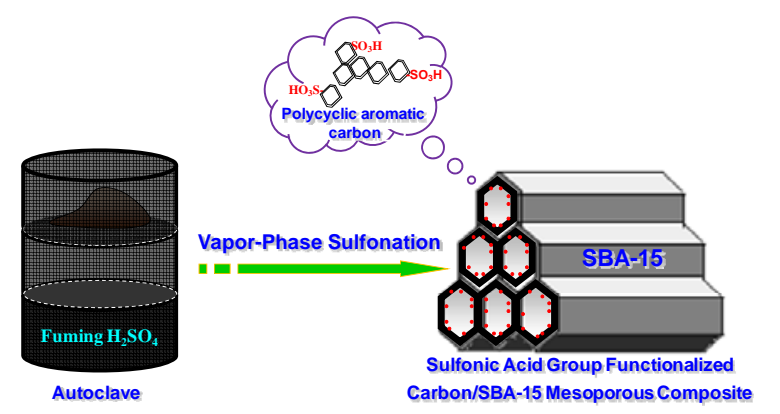

Fig. 1. Schematic of the preparation of $\mathrm{SO}_{3} \mathrm{H}$-functionalized carbon/SBA-15 mesoporous composites by moderate vapor phase sulfonation.

\subsection{Characterization}

Powder X-ray diffraction patterns were collected on a Bruker D8 ADVANCE instrument using $\mathrm{Cu} K_{\alpha}$ radiation ( $\lambda$ $=0.15418 \mathrm{~nm}$ ). $\mathrm{N}_{2}$ adsorption isotherms were measured at $77 \mathrm{~K}$ on a Quantachrome Autosorb-3B instrument after activating the sample at $423 \mathrm{~K}$ under vacuum for $24 \mathrm{~h}$. The scanning electron microscopy (SEM) images were obtained from a Hitachi S-4800 microscope. Fourier transform infrared (FT-IR) spectra were recorded on a Nicolet Fourier transform infrared spectrometer (NEXUS 670) using $\mathrm{KBr}$. The spectra of pyridine adsorption were measured by first treating the sample wafers at $403 \mathrm{~K}$ under vacuum for $5 \mathrm{~h}$ and then exposing to the pyridine vapor for $0.5 \mathrm{~h}$. Desorption of pyridine was carried out at different temperatures. The thermogravimetric (TG) analysis curves were obtained on a Mettler analyzer (TGA/SDTA 851e/5FL1100). The acid density was quantified by acid-base titration and the sulfur amount of $-\mathrm{SO}_{3} \mathrm{H}$-functional samples was determined by elemental analyses on a Perkin-Elmer series analyzer.

\subsection{Esterification and transesterification reactions}

In the esterification of palmitic acid and methanol, palmitic acid (0.8098 g, $3 \mathrm{mmol})$, methanol (2.8836 g, 90 $\mathrm{mmol})$, and $\mathrm{C} / \mathrm{CS}-\mathrm{SO}_{3} \mathrm{H}$ catalyst $(0.054 \mathrm{~g}, 7 \mathrm{wt} \%)$ were mixed in a closed container. The reaction was carried out at $343 \mathrm{~K}$ for $2 \mathrm{~h}$ under stirring. For the transesterification of soybean oil and methanol, SBO (2.0 g), methanol (2.0 g), and $0.1 \mathrm{~g} \mathrm{C} / \mathrm{CS}-\mathrm{SO}_{3} \mathrm{H}$ catalyst $(5 \mathrm{wt} \%)$ were used at $423 \mathrm{~K}$ for $3 \mathrm{~h}$. One-pot esterification/transesterification of the fatty acid/oil mixture with methanol was carried out similarly to the above mentioned transesterification by fixing the total $2.0 \mathrm{~g}$ of palimitic acid and SBO. For example, "30 \% palimitic acid $+70 \%$ SBO" means that $0.6 \mathrm{~g}$ palmitic acid and 1.4 $\mathrm{g}$ SBO were employed in the reaction. The products were analyzed and quantified on an FID GC (Shimadzu 14B) using eicosane as an internal standard.

\section{Results and discussion}

\subsection{Optimization of sulfonation}

Table 1 shows the investigation of the appropriate sulfonation conditions for the $\mathrm{C} / \mathrm{CS}$ precursor by either liquid phase impregnation with concentrated $\mathrm{H}_{2} \mathrm{SO}_{4}$ or direct vapor-to-solid transport with $\mathrm{H}_{2} \mathrm{SO}_{4} \cdot 20 \% \mathrm{SO}_{3}$. From the resulting $-\mathrm{SO}_{3} \mathrm{H}$ group density and catalytic conversion in the esterification of palmitic acid with methanol, the sulfonation with $\mathrm{H}_{2} \mathrm{SO}_{4} \cdot 20 \% \mathrm{SO}_{3}$ was superior to that with concentrated $\mathrm{H}_{2} \mathrm{SO}_{4}$.

Table 1 Optimization of sulfonation conditions for preparing $\mathrm{C} / \mathrm{CS}-\mathrm{SO}_{3} \mathrm{H}^{\mathrm{a}}$

\begin{tabular}{lcccc}
\hline Acid & $\begin{array}{c}\text { Temperature } \\
(\mathrm{K})\end{array}$ & $\begin{array}{c}\text { Time } \\
(\mathrm{h})\end{array}$ & $\begin{array}{c}\mathrm{S} \text { content } \\
(\mathrm{mmol} / \mathrm{g})\end{array}$ & $\begin{array}{c}\text { Conversion } \\
(\mathrm{mol} \%)\end{array}$ \\
\hline $\mathrm{H}_{2} \mathrm{SO}_{4}(98 \%)$ & 423 & 10 & 0.18 & 21 \\
$\mathrm{H}_{2} \mathrm{SO}_{4}(98 \%)$ & 423 & 24 & 0.13 & 10 \\
$\mathrm{H}_{2} \mathrm{SO}_{4}(98 \%)$ & 353 & 24 & 0.20 & 32 \\
$\mathrm{H}_{2} \mathrm{SO}_{4} \cdot 20 \% \mathrm{SO}_{3}$ & 353 & 24 & 0.44 & 88 \\
\hline
\end{tabular}

Esterification conditions: $3 \mathrm{mmol}$ palmitic acid, $90 \mathrm{mmol}$ methanol, 5 wt $\%$ catalyst, $343 \mathrm{~K}, 2 \mathrm{~h}$.

${ }^{\mathrm{a}} 25 \% \mathrm{C} / \mathrm{CS}$ was investigated with respect to sulfonation.

${ }^{\mathrm{b}}$ Determined by elemental analysis.

The conversion of palmitic acid was determined by the acid density obtained from the sulfonation of the C/CS composite precursor. The sulfonation with concentrated $\mathrm{H}_{2} \mathrm{SO}_{4}$ led to weaker acidity and a lower conversion even when the reaction was performed at higher temperatures or for a longer time. The $\mathrm{C} / \mathrm{CS}$ material was composed of the mesopores of SBA-15 by polycyclic aromatic carbon rings from the small amount of concentrated $\mathrm{H}_{2} \mathrm{SO}_{4}$ added or the thermal dehydration pyrolysis of sucrose at $673 \mathrm{~K}$. During the subsequent sulfonation in the liquid phase using concentrated $\mathrm{H}_{2} \mathrm{SO}_{4}$, there was electrophilic aromatic substitution 
by the sulfonic acid groups, and the mesoporous structure of SBA-15 in the composites was well preserved. However, the concentrated $\mathrm{H}_{2} \mathrm{SO}_{4}$ also further carbonized the polycyclic aromatic rings into carbon at the same time, which reduced the amount of substitution of sulfonic acid groups.

In the case of vapor phase sulfonation with $\mathrm{H}_{2} \mathrm{SO}_{4} \cdot 20 \% \mathrm{SO}_{3}$ using the same solid to liquid ratio, the acid site density and conversion of palmitic acid were both doubled (Table 1), showing that this sulfonation treatment was less harmful to the organic matrix, that is, the damage induced by the sulfonation was negligible. Thus, $\mathrm{H}_{2} \mathrm{SO}_{4}$. $20 \% \mathrm{SO}_{3}$ was adopted to prepare $\mathrm{C} / \mathrm{CS}-\mathrm{SO}_{3} \mathrm{H}$ materials with various carbon loadings by vapor phase sulfonation at 353 $\mathrm{K}$ for $24 \mathrm{~h}$.

\subsection{Characterization of the $\mathrm{C} / \mathrm{CS}-\mathrm{SO}_{3} \mathrm{H}$ materials}

\subsubsection{Structure of $\mathrm{C} / \mathrm{CS}-\mathrm{SO}_{3} \mathrm{H}$}

The carbon loading affected the textural parameters of the $\mathrm{C} / \mathrm{CS}-\mathrm{SO}_{3} \mathrm{H}$ composites, such as surface area, pore volume, pore size distribution, and accessibility of aromatic carbon rings to sulfonation. Figure 2 shows the low-angle XRD patterns. The peaks assigned to the [100], [110], and [200] diffractions of the 2D hexagonal structure $(p 6 \mathrm{~mm})$ of SBA-15 became weaker in intensity gradually as carbon filled the mesoporous channels. This can be attributed to diffraction interference from the carbon loaded and is not due to a collapse of the mesostructure [21]. In fact, when the carbon species in the $\mathrm{C} / \mathrm{CS}$ composite was burned off at 873 $\mathrm{K}$ in air, the XRD patterns were almost restored to those of the original silica (data not shown).

Loading with $35 \mathrm{wt} \%$ carbon covered the external channels, which increased the pore thickness and the diffraction peak was shifted to a lower angle (Fig. 2(5)). For the

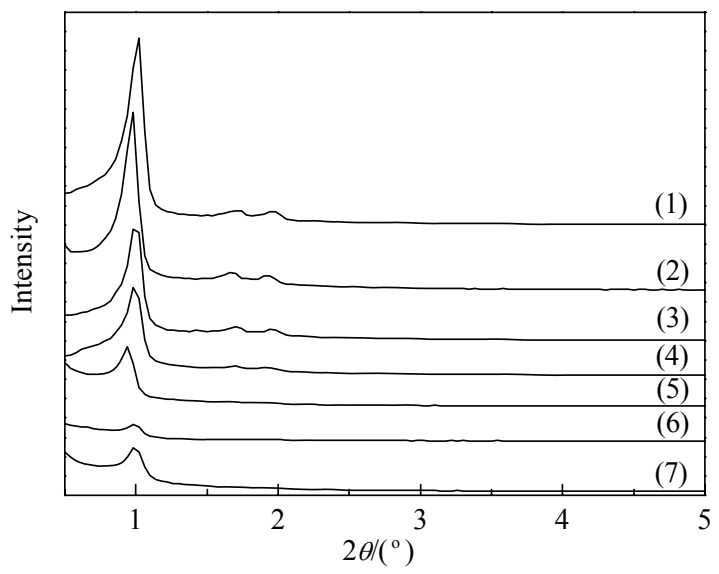

Fig. 2. $\mathrm{XRD}$ patterns of SBA-15 (1), $5 \% \mathrm{C} / \mathrm{CS}-\mathrm{SO}_{3} \mathrm{H}$ (2), $15 \% \mathrm{C} / \mathrm{CS}-\mathrm{SO}_{3} \mathrm{H} \quad(3), \quad 25 \% \mathrm{C} / \mathrm{CS}-\mathrm{SO}_{3} \mathrm{H} \quad(4), \quad 35 \% \mathrm{C} / \mathrm{CS}-\mathrm{SO}_{3} \mathrm{H} \quad(5)$, $45 \% \mathrm{C} / \mathrm{CS}-\mathrm{SO}_{3} \mathrm{H}(6)$, and $45 \% \mathrm{C}-\mathrm{CMK}-3-\mathrm{SO}_{3} \mathrm{H}(7)$.
$45 \% \mathrm{C} / \mathrm{CS}-\mathrm{SO}_{3} \mathrm{H}$ composite, the [100] diffraction peak intensity decreased more and it became boarder (Fig. 2(6)), implying that the channels were almost full. After it was treated with $15 \% \mathrm{HF}$ solution ( $1 \mathrm{~g}$ to $15 \mathrm{ml}$ ) to remove the silica template, the XRD pattern became stronger (Fig. 2(7)) due to the formation of sulfonated mesoporous carbon, CMK-3- $\mathrm{SO}_{3} \mathrm{H}$ [18].

The nitrogen adsorption-desorption isotherms and pore size distribution obtained for $\mathrm{C} / \mathrm{CS}-\mathrm{SO}_{3} \mathrm{H}$ are displayed in Fig. 3. SBA- 15 and $5 \%-35 \% \mathrm{C} / \mathrm{CS}-\mathrm{SO}_{3} \mathrm{H}$ showed Type IV isotherms with hysteresis loops in the $p / p_{0}$ range of $0.4-0.7$ (Fig. 3(a) (1)-(5)). The Type I isotherm of $45 \% \mathrm{C} / \mathrm{CS}-\mathrm{SO}_{3} \mathrm{H}$ revealed that micropores existed in this composite instead of mesopores (Fig. 3(a) (6)). 5\% C/CS-SO 3 H and 15\%C/CS$\mathrm{SO}_{3} \mathrm{H}$ exhibit a $\mathrm{H} 1$ type hysteresis loop similar to SBA-15 (Fig. 3(a) (1)-(3)), indicating that they probably have uniform cylindrical mesoporous channels covered with a monolayer dispersion of polycyclic aromatic carbon rings. The hysteresis loop of $25 \% \mathrm{C} / \mathrm{CS}-\mathrm{SO}_{3} \mathrm{H}$ appeared to be due to a two-step desorption (Fig. 3(a) (4)), suggesting the presence of both micro- and mesoporosity with open and en-
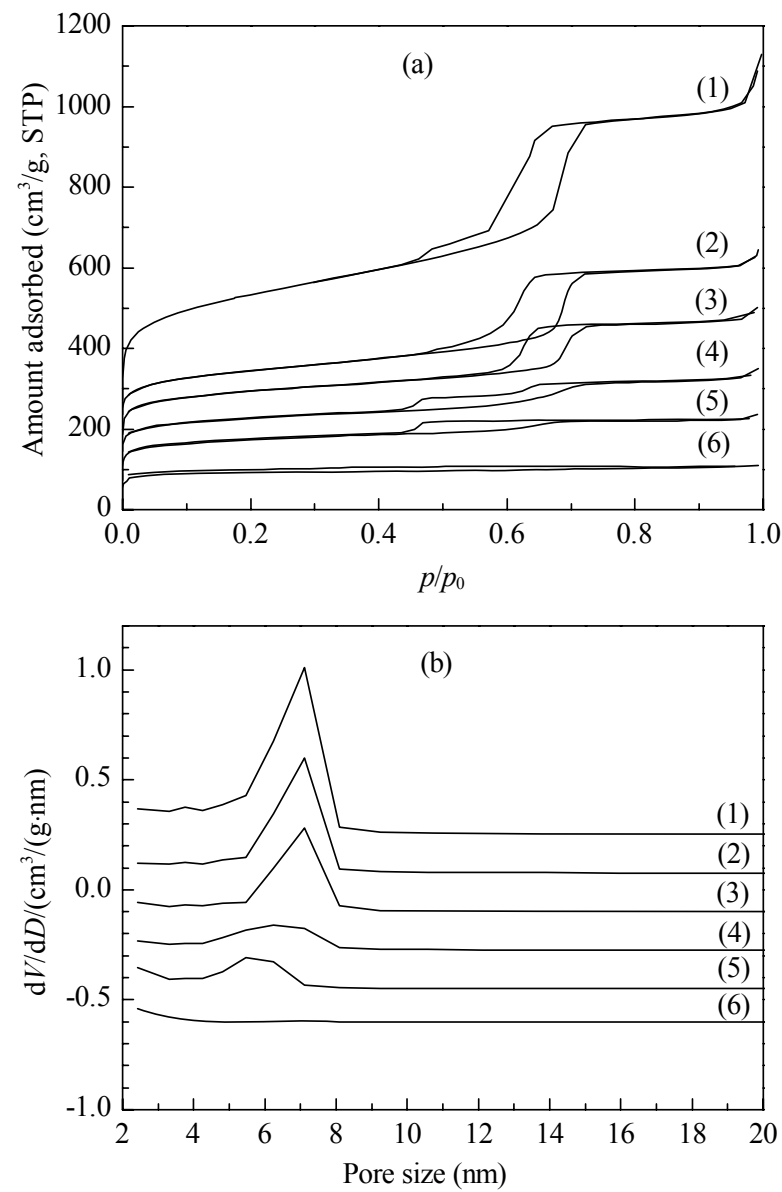

Fig. 3. $\mathrm{N}_{2}$ absorption-desorption isotherms (a) and pore distributions (b) for $\mathrm{SBA}-15$ (1), $5 \% \mathrm{C} / \mathrm{CS}-\mathrm{SO}_{3} \mathrm{H}$ (2), $15 \% \mathrm{C} / \mathrm{CS}-\mathrm{SO}_{3} \mathrm{H} \quad$ (3), $25 \% \mathrm{C} / \mathrm{CS}-\mathrm{SO}_{3} \mathrm{H}(4), 35 \% \mathrm{C} / \mathrm{CS}-\mathrm{SO}_{3} \mathrm{H}(5)$, and $45 \% \mathrm{C} / \mathrm{CS}-\mathrm{SO}_{3} \mathrm{H}(6)$. 
capsulated mesopores [22]. The carbon accumulated would cause blocking of the channels. Increasing the carbon loading to $35 \mathrm{wt} \%$ caused the hysteresis loop to change from $\mathrm{H} 1$ to H2 type, which was probably due to the "ink bottle" effect (Fig. 3(a) (5)).

The same trend was observed in the pore size distribution
(Fig. 2(b)). The deposition of carbon into the SBA-15 channels diminished the original mesopores with a regular size of $\sim 7 \mathrm{~nm}$. In the case of $45 \% \mathrm{C} / \mathrm{CS}-\mathrm{SO}_{3}$, complete blockage had converted the composite into a material with the characteristic of microporosity, where the micropores accounted for $76 \%$ of the total pore volume (Table 2 ).

Table 2 Physicochemical properties of $\mathrm{C} / \mathrm{CS}-\mathrm{SO}_{3} \mathrm{H}$ catalysts

\begin{tabular}{|c|c|c|c|c|c|c|c|}
\hline \multirow{2}{*}{ Sample } & \multirow{2}{*}{$\begin{array}{c}\text { Carbon loading }{ }^{\mathrm{a}} \\
(\mathrm{wt} \%)\end{array}$} & \multirow{2}{*}{$\begin{array}{c}S_{\mathrm{BET}} / \\
\left(\mathrm{m}^{2} / \mathrm{g}\right)\end{array}$} & \multicolumn{3}{|c|}{ Pore volume $\left(\mathrm{cm}^{3} / \mathrm{g}\right)$} & \multirow{2}{*}{$\begin{array}{c}\mathrm{H}^{+\mathrm{b}} \\
(\mathrm{mmol} / \mathrm{g})\end{array}$} & \multirow{2}{*}{$\begin{array}{l}\text { S content }^{\mathrm{c}} \\
(\mathrm{mmol} / \mathrm{g})\end{array}$} \\
\hline & & & $V_{\text {total }}$ & $V_{\text {micro }}{ }^{\mathrm{d}}$ & $V_{\text {micro }}{ }^{\mathrm{e}} / \%$ & & \\
\hline SBA-15 & 0 & 978 & 1.31 & 0.12 & 9 & - & - \\
\hline $5 \% \mathrm{C} / \mathrm{CS}-\mathrm{SO}_{3} \mathrm{H}$ & 5.5 & 437 & 0.55 & 0.07 & 14 & 0.09 & 0.06 \\
\hline $15 \% \mathrm{C} / \mathrm{CS}-\mathrm{SO}_{3} \mathrm{H}$ & 14.7 & 425 & 0.40 & 0.12 & 30 & 0.33 & 0.24 \\
\hline $25 \% \mathrm{C} / \mathrm{CS}-\mathrm{SO}_{3} \mathrm{H}$ & 24.2 & 358 & 0.38 & 0.13 & 34 & 0.52 & 0.44 \\
\hline $35 \% \mathrm{C} / \mathrm{CS}-\mathrm{SO}_{3} \mathrm{H}$ & 33.4 & 339 & 0.29 & 0.14 & 48 & 0.70 & 0.54 \\
\hline $45 \% \mathrm{C} / \mathrm{CS}-\mathrm{SO}_{3} \mathrm{H}$ & 41.4 & 272 & 0.17 & 0.13 & 76 & 0.16 & 0.68 \\
\hline
\end{tabular}

${ }^{\mathrm{a}}$ Carbon content determined by TG analysis. ${ }^{\mathrm{b}}$ By acid-base titration. ${ }^{\mathrm{c}}$ By elemental analysis. ${ }^{\mathrm{d}}$ From $t$-plots. ${ }^{\mathrm{e}}$ Percentage of micropore relative to total pore volume.

The SEM images (Fig. 4) showed that the typical 2D periodic hexagonal structure of SBA-15 was retained after incorporation of sucrose and sulfonation independent of carbon loading. With the increase of carbon loading in SAB-15 silica, the mesopores were blocked to form micropores as exhibited by $\mathrm{N}_{2}$ physisorption. When the carbon amount was too much, e.g. $45 \% \mathrm{C} / \mathrm{CS}-\mathrm{SO}_{3} \mathrm{H}$, part of the carbon covered the external surface of SBA-15 (Fig. 4(f)). The specific surface area was lowered to be less than $30 \%$ of the parent SAB-15 (Table 2, No. 6).
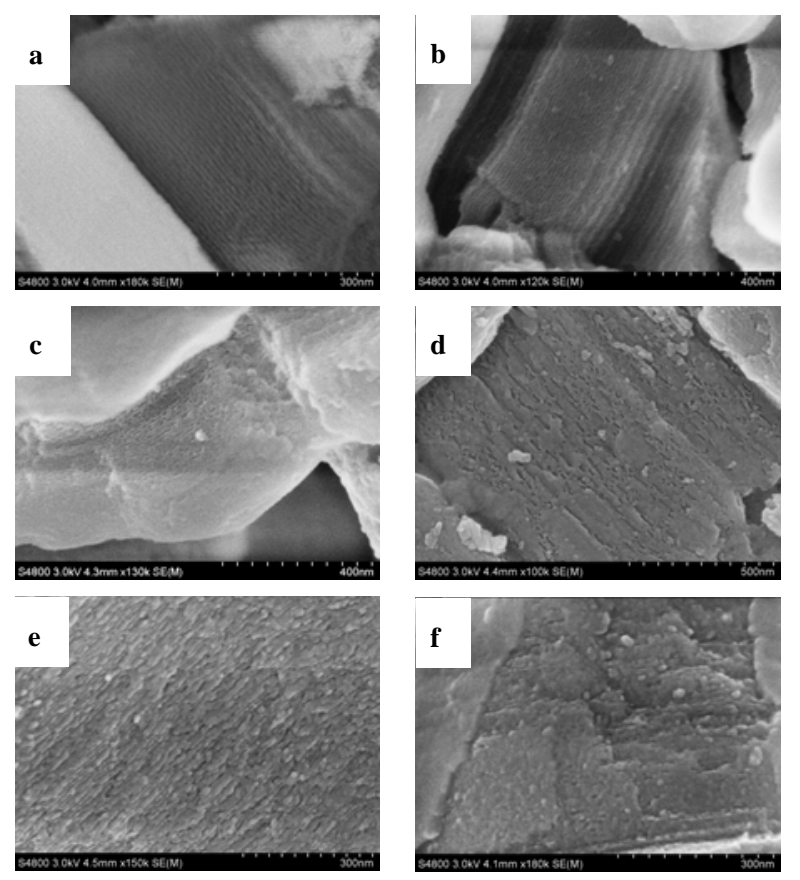

Fig. 4. SEM images of SBA-15 (a), $5 \% \mathrm{C} / \mathrm{CS}-\mathrm{SO}_{3} \mathrm{H}$ (b), $15 \% \mathrm{C} / \mathrm{CS}-\mathrm{SO}_{3} \mathrm{H}$ (c), $25 \% \mathrm{C} / \mathrm{CS}-\mathrm{SO}_{3} \mathrm{H}(\mathrm{d}), 35 \% \mathrm{C} / \mathrm{CS}-\mathrm{SO}_{3} \mathrm{H}$ (e), and $45 \% \mathrm{C} / \mathrm{CS}-\mathrm{SO}_{3} \mathrm{H}(\mathrm{f})$.

\subsubsection{Acidity of $\mathrm{C} / \mathrm{CS}-\mathrm{SO}_{3} \mathrm{H}$}

Figure 5 presents the TG-DTG curves measured under an air atmosphere for $25 \% \mathrm{C} / \mathrm{CS}$ and its sulfonated counterpart. Compared with the $\mathrm{C} / \mathrm{CS}$ precursor, $25 \% \mathrm{C} / \mathrm{CS}-\mathrm{SO}_{3} \mathrm{H}$ showed $10 \%$ more weight loss as a result of the grafting of sulfonic groups and more water adsorbed. The weight loss started earlier at $400 \mathrm{~K}$ instead of at $600 \mathrm{~K}$ for $25 \% \mathrm{C} / \mathrm{CS}$, indicating that some other species existed in the composite, which was attributed to physically adsorbed fuming sulfuric acid or carboxylic acid groups $(-\mathrm{COOH})$ that were possibly formed in the carbonation process. In the temperature range of $600-900 \mathrm{~K}, 25 \% \mathrm{C} / \mathrm{CS}$ had lost $24.2 \%$ weight, which was approximately equal to the pure carbon content in the composite (Table 2). TG analysis confirmed that sulfonic groups were formed during the vapor phase sulfonation treatment.

Figure 6 shows the FT-IR spectra for $25 \% \mathrm{C} / \mathrm{CS}-\mathrm{SO}_{3} \mathrm{H}$.

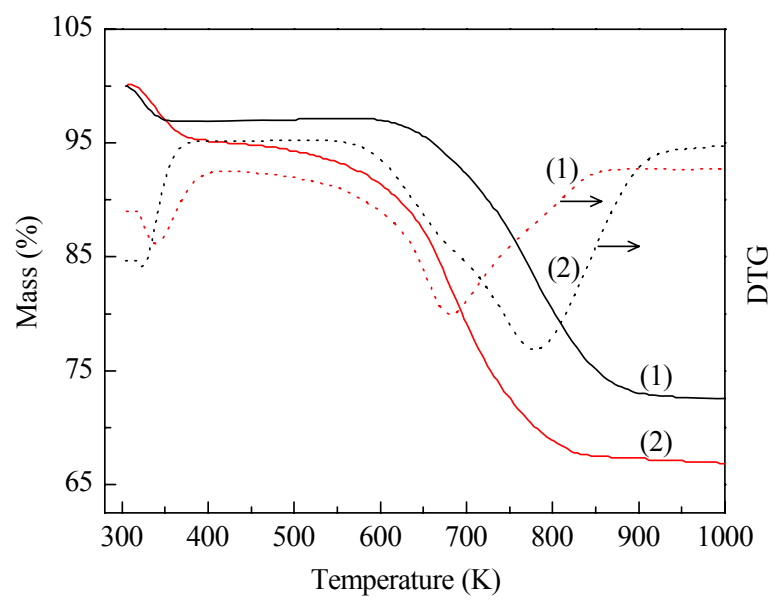

Fig. 5. TG-DTG curves of $25 \% \mathrm{C} / \mathrm{CS}(1)$ and $25 \% \mathrm{C} / \mathrm{CS}-\mathrm{SO}_{3} \mathrm{H}(2)$. 
Because the stretching vibrations of $\mathrm{SiO}_{2}$ overlapped the bands of the other species in range of $1000-1300 \mathrm{~cm}^{-1}$, direct observation of the symmetric stretching of $\mathrm{S}=\mathrm{O}$ is impossible (Fig. 6(1)). HF acid (15\%) was used to remove the silica template in $25 \% \mathrm{C} / \mathrm{CS}$ and $25 \% \mathrm{C} / \mathrm{CS}-\mathrm{SO}_{3} \mathrm{H}$, and this process was repeated three times. The characteristic band at $1032 \mathrm{~cm}^{-1}$ attributed to the sulfonic acid group then became clearly visible, except for sample $25 \% \mathrm{C} / \mathrm{CS}$ that was not sulfonated (Fig. 6(2) and (3)).

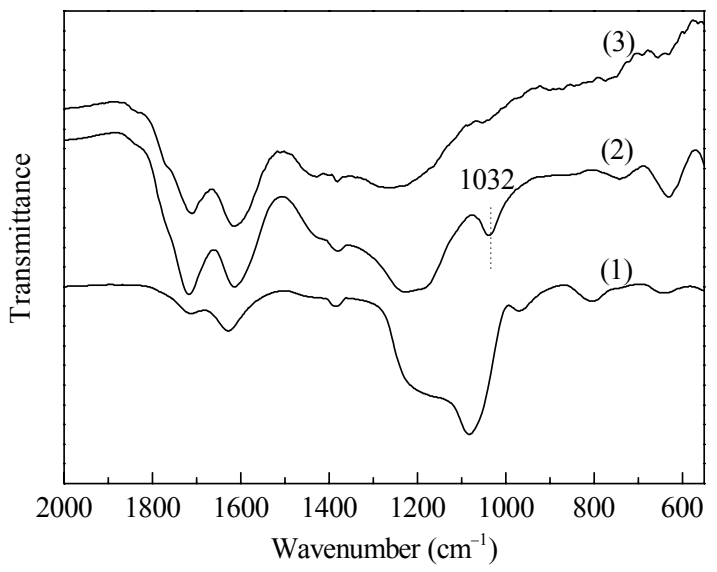

Fig. 6. IR spectra of $25 \% \mathrm{C} / \mathrm{CS}-\mathrm{SO}_{3} \mathrm{H}(\mathrm{a}), 25 \% \mathrm{C} / \mathrm{CS}-\mathrm{SO}_{3} \mathrm{H}$ after removal of Silica with $15 \% \mathrm{HF}$ (b), and $25 \% \mathrm{C} / \mathrm{CS}$ after removal of silica with $15 \%$ HF solution (c).

Pyridine was employed as the probe molecule to provide more detailed information about acid site types, distribution, strength and density. Figure 7 shows the spectra of pyridine adsorbed on $35 \% \mathrm{C} / \mathrm{CS}-\mathrm{SO}_{3} \mathrm{H}$ followed by the desorption of physically adsorbed pyridine at $423 \mathrm{~K}$ and the spectra after evacuation at higher temperatures. Three characteristic bands were observed at 1547,1445 , and $1490 \mathrm{~cm}^{-1}$ in the region of the pyridine ring vibrations. These were evidence

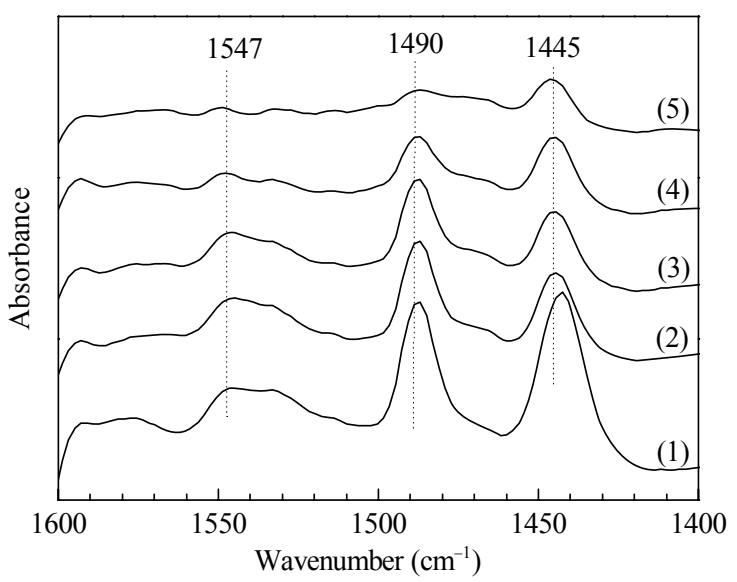

Fig. 7. IR spectra of pyridine adsorbed on $35 \% \mathrm{C} / \mathrm{CS}-\mathrm{SO}_{3} \mathrm{H}$ after desorption at 323 (1), 423 (2), 473 (3), 523 (4), and $573 \mathrm{~K}(5)$. for the presence of Brønsted acid sites, weakly acidic hydroxyl groups $(-\mathrm{OH})$ or Lewis acid sites and both [23]. The $\mathrm{C} / \mathrm{CS}-\mathrm{SO}_{3} \mathrm{H}$ composite with sulfonic acid groups acted as a strong Brønsted acid. These may be also accompanied by carboxylic acid groups $(-\mathrm{COOH})$ generated from the pyrolysis of the polycyclic aromatic rings [19]. In addition, SBA-15 has plentiful weak Lewis acid sites or hydroxyl groups that adsorb pyridine physically.

The band due to hydrogen-bonded pyridine was relatively resistant to evacuation but decreased in intensity with rising desorption temperature. Desorption at $573 \mathrm{~K}$ caused the band at $1445 \mathrm{~cm}^{-1}$ to totally disappear (Fig. 7(5)). The 1547 $\mathrm{cm}^{-1}$ band was also diminished, indicating that some pyridium ions were leached from the Brønsted acid sites. Two reasons could account for this observation: thermal desorption removed pyridium ions from the acid sites gradually or the substituted sulfonic acid groups were cleaved off from the carbon matrix at high temperature. The temperature of $423 \mathrm{~K}$ was chosen for removing the hydrogen-bonded pyridine (Fig. 7(2)).

After removing weakly or physically adsorbed pyridine species by evacuation at $423 \mathrm{~K}$, the $\mathrm{C} / \mathrm{CS}-\mathrm{SO}_{3} \mathrm{H}$ composites all exhibited the characteristic band at $1547 \mathrm{~cm}^{-1}$ (Fig. 8(3)-(7)). However, this band was absent from the sulfonic group-free samples of SBA-15 and 35\%C/CS (Fig. 8(1) and (2)). This confirmed that $\mathrm{H}_{2} \mathrm{SO}_{4}$ added for the pyrolysis of sucrose did not generate Brønsted acid sites, and that the carboxylic acid group $(-\mathrm{COOH})$ possibly formed in carbonation process was not acidic enough to protonate pyridine into the pyridium ion [18].

The bands at 1547 and $1490 \mathrm{~cm}^{-1}$ increased in intensity with increasing carbon content from $5 \%$ to $35 \%$ and then decreased at $45 \%$ carbon loading (Fig. 8(3)-(7)). It seemed reasonable to believe that more loading of polycyclic aro-

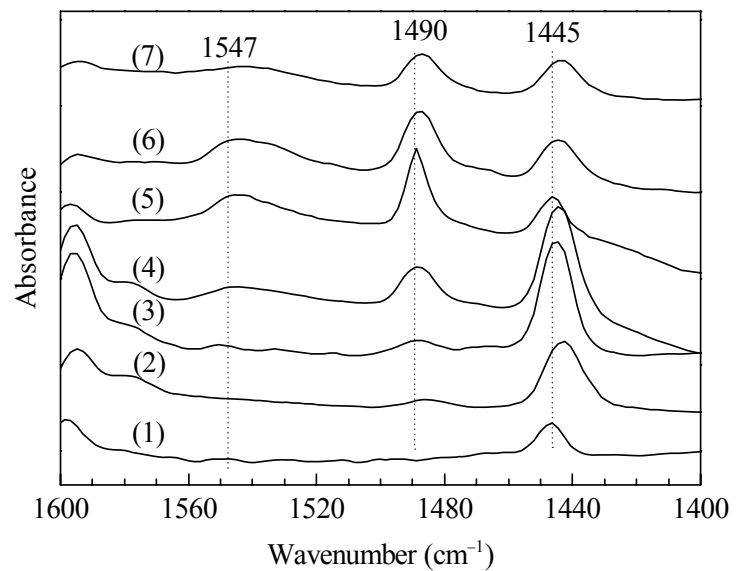

Fig. 8. IR spectra of adsorbed pyridine after desorption at $423 \mathrm{~K}$ for SBA-15 (1), 35\%C/CS (2), 5\%C/CS-SO ${ }_{3} \mathrm{H}$ (3), 15\%C/CS- $\mathrm{SO}_{3} \mathrm{H}$ (4), $25 \% \mathrm{C} / \mathrm{CS}-\mathrm{SO}_{3} \mathrm{H}(5), 35 \% \mathrm{C} / \mathrm{CS}-\mathrm{SO}_{3} \mathrm{H}(6)$, and $45 \% \mathrm{C} / \mathrm{CS}-\mathrm{SO}_{3} \mathrm{H}(7)$. 
matic rings would produce more sulfonic acid groups. However, this was not the case. This may be due to that the growing bulk carbon in the mesopores may prevent the sulfonic acid groups from attacking the aromatic rings by diffusion limitation, resulting in less acid sites than expected. Consequently, the intensity of the bands at 1547 and 1490 $\mathrm{cm}^{-1}$ was reduced with the increase of sucrose impregnation. The IR spectra of pyridine adsorption clearly indicated that there was a balance between the acid density and pore spacing in the composite. The adsorption of pyridine, with a relatively bulky molecular dimension, may provide information about whether the acid sites were really accessible and useful in catalytic reactions.

The amount of pyridine coordinated to Lewis acid sites or hydrogen-bonded to the $-\mathrm{OH}$ and $-\mathrm{COOH}$ groups on aromatic rings was shown by the intensity of the band at 1445 $\mathrm{cm}^{-1}$ (Fig. 8(1) and (2)). The sulfonation generated more weak acid sites as the band increased in intensity from 5 $\mathrm{wt} \%$ to $15 \mathrm{wt} \%$ carbon loading but this decreased from 25 wt $\%$ to 45 wt $\%$ loading (Fig. 8(3)-(7)). This was evidence that accessible Lewis or weak acid sites became less as a result of pore blocking.

The influences of the carbon loading on the sulfur content, acid amount and intensity of the $1547 \mathrm{~cm}^{-1}$ IR band are summarized in Fig. 9. All sulfonated samples had considerable acid amounts (see also Table 2). According to the acid-base titration data and the band intensity at $1547 \mathrm{~cm}^{-1}$, the amount increased from $5 \mathrm{wt} \%$ carbon, reached a maximum at $35 \mathrm{wt} \%$, and then decreased at $45 \mathrm{wt} \%$. The elemental analysis showed that the sulfur amount was almost proportional to the carbon loading in the investigated range of $5 \mathrm{wt} \%-45 \mathrm{wt} \%$. The abnormally higher $\mathrm{S}$ content at 45 $\mathrm{wt} \%$ carbon loading may be associated with the residual $\mathrm{S}$ added in the pyrolysis step rather than as due to increased sulfonic acid groups from the sulfonation procedure.

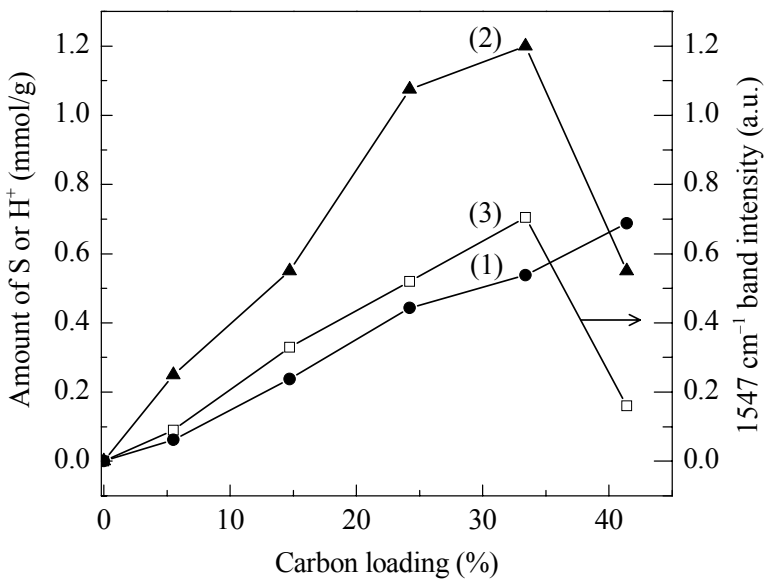

Fig. 9. Dependence of sulfur content (1), acid amount (2), and 1547 $\mathrm{cm}^{-1}$-IR band intensity (3) on the carbon loading of C/CS-SO ${ }_{3} \mathrm{H}$.

\subsection{Catalytic properties of $\mathrm{C} / \mathrm{CS}-\mathrm{SO}_{3} \mathrm{H}$}

\subsubsection{Esterification and transesterification on $25 \% \mathrm{C} / \mathrm{CS}-\mathrm{SO}_{3} \mathrm{H}$}

Figure 10 shows the effect of temperature and catalyst amount on the esterification of palmitic acid and methanol. The fatty acid ester product increased with increasing temperature and reached a maximum value at $343 \mathrm{~K}$ (Fig. 10(a)). At this temperature, the conversion was already above $90 \%$ at $5 \%$ catalyst amount relative to palmitic acid, and it was as high as $99 \%$ with $7 \%$ catalyst (Fig. 10(b)). The slow kinetic rate normally requires that acid-catalyzed transesterification be performed at much higher temperatures than that used for the base-catalyzed reaction. A similar conclusion has been drawn when tungstated zirconia alumina, sulfated zirconia alumina, and sulfated tin oxide were used as super solid acid catalysts for the production of biodiesels [24,25].
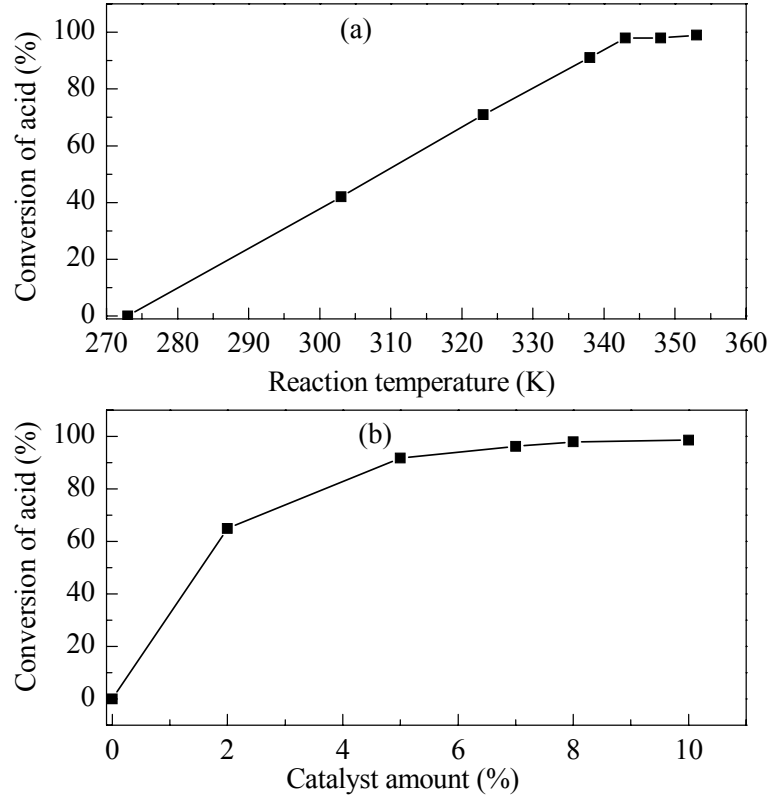

Fig. 10. Effect of reaction temperature (a) and catalyst amount (b) on the esterification of palm acid with methanol on $25 \% \mathrm{C} / \mathrm{CS}-\mathrm{SO}_{3} \mathrm{H}$. Reaction conditions: $3 \mathrm{mmol}$ palm acid, $90 \mathrm{mmol}$ methanol, $2 \mathrm{~h}$.

Figure 11 (a) shows the effect of reaction temperature on the transesterification of SBO and methanol over $25 \% \mathrm{C} / \mathrm{CS}$ $\mathrm{SO}_{3} \mathrm{H}$ catalyst. The temperature played a key role on the yield of transesterification. The catalytic activity showed a steep jump at $403 \mathrm{~K}$ where the yield of esters reached $90 \%$ after reaction for $3 \mathrm{~h}$ with $5 \%$ catalyst. The yield of $99 \%$ was obtained by increasing the reaction temperature to 423 $\mathrm{K}$. The influence of carbon loading on the transesterification on $\mathrm{C} / \mathrm{CS}-\mathrm{SO}_{3} \mathrm{H}$ is shown in Fig. 11(b). The highest ester yield was reached over $25 \% \mathrm{C} / \mathrm{CS}-\mathrm{SO}_{3} \mathrm{H}$ instead of 

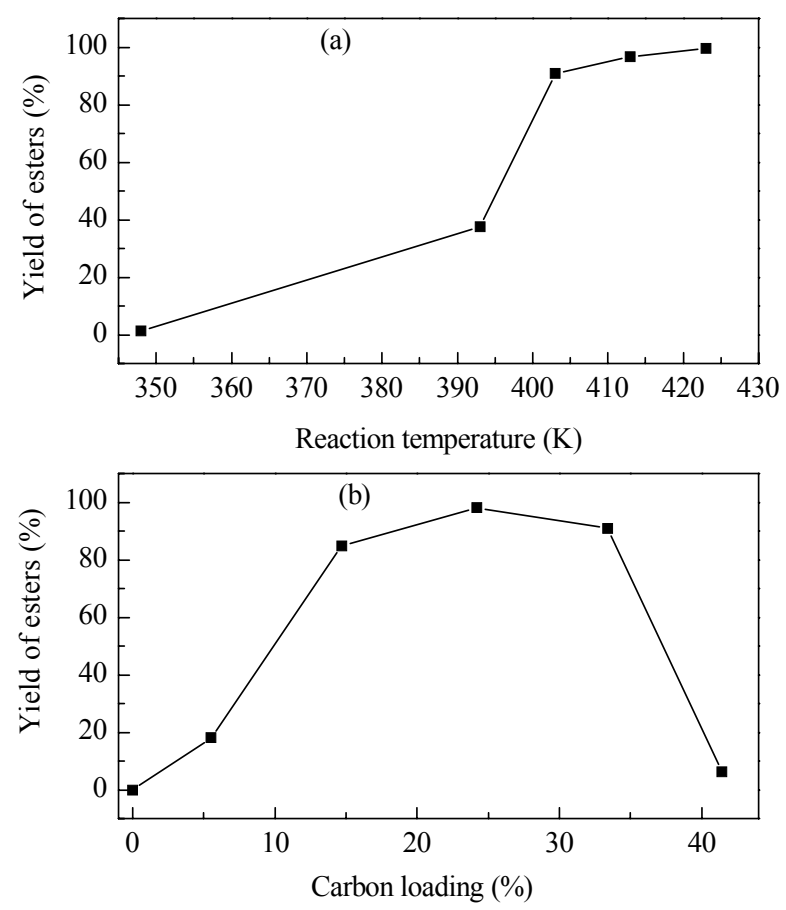

Fig. 11. Effect of reaction temperature (a) and carbon loading of $\mathrm{C} / \mathrm{CS}$ (b) on the transesterification of SBO and methanol. Reaction conditions: $2 \mathrm{~g}$ SBO, $2 \mathrm{~g} \mathrm{MeOH}, 5 \mathrm{wt} \%$ catalyst, $3 \mathrm{~h}$.

$35 \% \mathrm{C} / \mathrm{CS}-\mathrm{SO}_{3} \mathrm{H}$. As we mentioned above, the activity of sulfonic group functionalized carbon/SBA-15 composite with different carbon loadings probably correlates with the access availability of active Brønsted acid sites in the mesopores.

Figure 12 shows the dependence of SBO transesterification activity on the amount of Brønsted acid sites in $\mathrm{C} / \mathrm{CS}-\mathrm{SO}_{3} \mathrm{H}$ composites. The " $\mathrm{S}$ " shape curve further implied that the ester yield was restricted by the surface area. $45 \% \mathrm{C} / \mathrm{CS}-\mathrm{SO}_{3} \mathrm{H}$ with a lower surface area gave only $10 \%$ yield in spite of its showing a comparable $1547 \mathrm{~cm}^{-1}$ band to that of $5 \% \mathrm{C} / \mathrm{CS}-\mathrm{SO}_{3} \mathrm{H}$. The latter with more open chan-

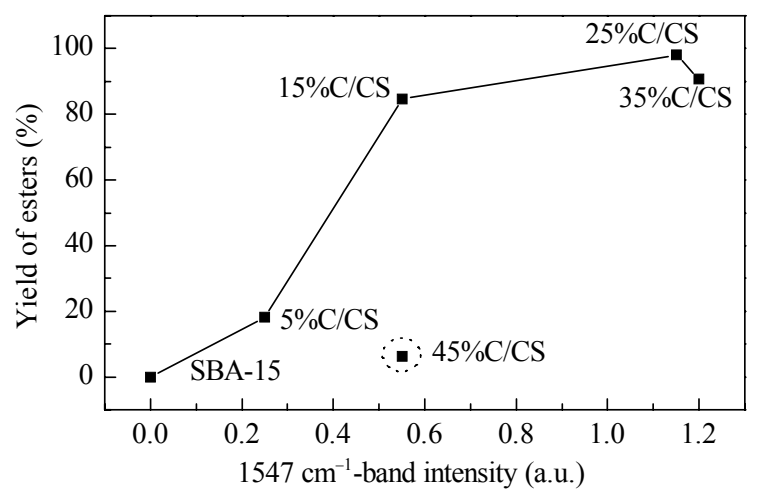

Fig. 12. Dependence of SBO transesterification activity on the Brønsted acid sites of $\mathrm{C} / \mathrm{CS}-\mathrm{SO}_{3} \mathrm{H}$ catalysts. Reaction conditions: $2 \mathrm{~g} \mathrm{SBO}$, $2 \mathrm{~g} \mathrm{MeOH}, 5 \mathrm{wt} \%$ catalyst, $423 \mathrm{~K}, 3 \mathrm{~h}$. nels gave $85 \%$ ester yield. It is interesting to note that the used catalyst can be readily recovered by simple filtration, washing, and drying, and the activity remained unchanged after three recycle use, indicating that the $\mathrm{CS}-\mathrm{SO}_{3} \mathrm{H}$ catalysts were robust and stable.

\subsubsection{Esterification and transesterification on various catalysts}

For comparisons, commercial proton-exchanged resins of Amberlyst-15 and Dowex 50WX2-100 and sugar- $\mathrm{SO}_{3} \mathrm{H}$ were used for the production of biodiesels. The data are listed in Table 3. Even with the lowest acid amount, $\mathrm{C} / \mathrm{CS}-\mathrm{SO}_{3} \mathrm{H}$ showed a superior catalytic activity for both esterification and transesterification under the same conditions to the other catalysts. The specific activity expressed as the turnover frequency (TOF) also verified that $\mathrm{C} / \mathrm{CS}-\mathrm{SO}_{3} \mathrm{H}$ was the most active catalyst. The sugar- $\mathrm{SO}_{3} \mathrm{H}$ catalyst with a hydrophobic nature had a high affinity for the organic phase, but its low specific surface area $\left(2 \mathrm{~m}^{2} / \mathrm{g}\right)$ had limited active sites, resulting in lower activity [1]. Even though proton-exchanged resins have many more acid active sites and considerable surface area, the leaching of the active Brønsted acid sites of Amberlyst-15 and Dowex 50WX2-100 during reaction has to be considered.

Table 3. Textural properties and activity of used catalysts

\begin{tabular}{|c|c|c|c|c|}
\hline Catalyst & $\begin{array}{c}S_{\mathrm{BET}} / \\
\left(\mathrm{m}^{2} / \mathrm{g}\right)\end{array}$ & $\begin{array}{c}\text { Acid } \\
\text { amount }^{\mathrm{a}} \\
(\mathrm{mmol} / \mathrm{g})\end{array}$ & $\begin{array}{l}\text { Conversion } \\
\text { of } \\
\text { eterification }^{\mathrm{b}} \\
\quad(\mathrm{mol} \%)\end{array}$ & $\begin{array}{l}\text { Yield of } \\
\text { transesteri- } \\
\text { fication }^{\mathrm{c}} \\
(\mathrm{wt} \%)\end{array}$ \\
\hline $25 \% \mathrm{C} / \mathrm{CS}-\mathrm{SO}_{3} \mathrm{H}$ & 358 & 0.52 & $98.0(52.4)$ & 99.0 \\
\hline Sugar- $\mathrm{SO}_{3} \mathrm{H}$ & 2 & 1.0 & $80.4(22.3)$ & 88.9 \\
\hline Amberlyst- 15 & $\sim 50$ & 4.6 & $38.7(2.3)$ & 40.9 \\
\hline Dowex 50WX2-100 & $\sim 10$ & 0.60 & $46.9(21.7)$ & 26.7 \\
\hline
\end{tabular}

${ }^{\mathrm{a}}$ By acid-base titration. ${ }^{\mathrm{b}}$ Esterification conditions: $3 \mathrm{mmol}$ palm acid, 90 mmol MeOH, $7 \mathrm{wt} \%$ catalyst, $343 \mathrm{~K}, 2 \mathrm{~h}$. The number in parentheses indicates the TOF in $\mathrm{h}^{-1}$. ${ }^{\mathrm{c}}$ Transesterification conditions: $2 \mathrm{~g} \mathrm{SBO}, 2 \mathrm{~g}$ $\mathrm{MeOH}, 5 \mathrm{wt} \%$ catalyst, $423 \mathrm{~K}, 3 \mathrm{~h}$.

\subsubsection{One-pot transesterification and esterification of fatty acid and SBO mixture on $25 \% \mathrm{C} / \mathrm{CS}-\mathrm{SO}_{3} \mathrm{H}$}

Even in the presence of palmitic acid, the solid acid catalyst displayed outstanding catalytic performance in the one-pot transesterification and esterification. A series of palmitic acid/SBO mixtures were prepared by blending $10 \%, 30 \%, 50 \%, 70 \%$, or $90 \%$ palmitic acid in SBO to simulate the waste oil used in biodiesel production. $25 \% \mathrm{C} / \mathrm{CS}-\mathrm{SO}_{3} \mathrm{H}$ displayed remarkable catalytic performance for independent esterification and transesterification (Table 4, Nos. 1 and 7). When SBO was blended with 
palmitic acid up to $70 \%$, the ester yield was only slightly lowered to $94.4 \%$ (Table 4 , Nos. 2-5). In the case of the mixture containing $90 \%$ palmitic acid, the ester yield was even augmented slightly to $95.3 \%$ (Table 4 , No. 6). The use of fairly pure palmitic acid as the reactant tended to lower the thermodynamic threshold of the esterification because of the formation of a large quantity of water byproduct. However, the one-pot transesterification and esterification of the acid/SBO mixture were performed at a high temperature that was higher than the $333 \mathrm{~K}$ used for esterification. This would weaken the negative influence of co-existing fatty acid on the whole reaction. Moreover, the acid sites located on the carbon with a hydrophobic nature may also benefit the $\mathrm{C} / \mathrm{CS}-\mathrm{SO}_{3} \mathrm{H}$-catalyzed reactions involving fatty acid. Hence, $\mathrm{C} / \mathrm{CS}-\mathrm{SO}_{3} \mathrm{H}$ is a promising catalyst for the production of biodiesel by the one-pot transesterification and esterification of waste oil.

Table 4. Esterication/transesterification of fatty acid and soybean oil mixture on $\mathrm{C} / \mathrm{CS}-15-\mathrm{SO}_{3} \mathrm{H}$ catalyst ${ }^{\mathrm{a}}$

\begin{tabular}{lcrrcc}
\hline No. & \multicolumn{2}{c}{ Substrates $(\mathrm{wt} \%)$} & Temperature & $\begin{array}{c}\text { Time } \\
(\mathrm{K})\end{array}$ & $\begin{array}{c}\text { Conversion or } \\
(\mathrm{h})\end{array}$ \\
\cline { 2 - 3 } & Palmitic acid & SBO & & yield $(\%)$ \\
\hline $1^{\mathrm{b}}$ & 100 & 0 & 343 & 2 & 98.0 \\
2 & 10 & 90 & 423 & 3 & 99.6 \\
3 & 30 & 70 & 423 & 3 & 98.7 \\
4 & 50 & 50 & 423 & 3 & 96.6 \\
5 & 70 & 30 & 423 & 3 & 94.4 \\
6 & 90 & 10 & 423 & 3 & 95.3 \\
7 & 0 & 100 & 423 & 3 & 99.0 \\
\hline
\end{tabular}

${ }^{\mathrm{a}}$ Transesterification conditions: $2 \mathrm{~g}$ mixture of SBO and palmitic acid, 2 $\mathrm{g} \mathrm{MeOH}, 5 \mathrm{wt} \%$ catalyst.

${ }^{\mathrm{b}}$ Esterification conditions: $3 \mathrm{mmol}$ palmitic acid, $90 \mathrm{mmol} \mathrm{MeOH}, 7$ $\mathrm{wt} \%$ catalyst.

\section{Conclusions}

Sulfonic acid group functionalized carbon/SBA-15 composite with well-ordered mesopores and considerable amounts of Brønsted acid sites was prepared by a carefully controlled sulfonation method. The catalysts were stable, highly active and selective solid acid catalysts for the production of biodiesel by the esterification of palmitic acid and the transesterification of soybean oil with methanol. They were also highly efficient in the one-pot esterification and transesterification of fatty acid-containing soybeanoil. For the design of the sulfonic acid group functionalized carbon/mesosilica composite for catalytic reactions involving bulky molecules, it is important to take into account the density, distribution, and accessibility of the resulting Brønsted acid sites.

\section{References}

1 Hara M. Energy Environ Sci, 2010, 3: 601

2 Yang P F, Kobayashi H, Fukuoka A. Chin J Catal (催化学报), 2011, 32: 716

3 Shibasaki-Kitakawa N, Honda H, Kuribayashi H, Toda T, Fukumura T, Yonemoto T. Bioresour Technol, 2007, 98: 416

4 Serio M D, Tesser R, Dimiccoli M, Cammarota F, Nastasi M, Santacesaria E. J Mol Catal A, 2005, 239: 111

5 Liu K S. J Am Oil Chem Soc, 1994, 71: 1179

6 Shu Q, Yang B, Yuan H, Qing S, Zhu G. Catal Commun, 2007, 8: 2159

7 Nakagaki S, Bail A, Cristina dos Santos V, Rodrigues de Souza V H, Vrubel H, Nunes F S, Ramos L P. Appl Catal A, 2008, 351: 267

8 Ghesti G F, Lemos de Macedo J, Parente V C I, Dias J A, Dias S C L. Appl Catal A, 2008, 355: 139

9 Jacobson K, Gopinath R, Meher L C, Dalai A K. Appl Catal B, 2008, 85: 86

10 Kresge C T, Leonowicz M E, Roth W J, Vartuli J C, Beck J S. Nature, 1992, 359: 710

11 Zhao D, Feng J, Huo Q, Melosh N, Fredrickson G H, Chmelka B F, Stucky G D. Science, 1998, 279: 548

12 Margolese D, Melero J A, Christiansen S C, Chmelka B F, Stucky G D. Chem Mater, 2000, 12: 2448

13 Shen J G C, Herman R G, Klier K. J Phys Chem B, 2002, 106: 9975

14 Bossaert W D, De Vos D E, Van Rhijn W M, Bullen J, Grobet P J, Jacobs P A. J Catal, 1999, 182: 156

15 Díaz I, Mohino F, Blasco T, Sastre E, Pérez-Pariente J. Microporous Mesoporous Mater, 2005, 80: 33

16 Toda M, Takagaki A, Okamura M, Kondo J N, Hayashi S, Domen K, Hara M. Nature, 2005, 438: 178

17 Xing R, Liu N, Liu Y M, Wu H H, Jiang Y W, Chen L, He M Y, Wu P. Adv Funct Mater, 2007, 17: 2455

18 Xing R, Liu Y M, Wang Y, Chen L, Wu H H, Jiang Y W, He M Y, Wu P. Microporous Mesoporous Mater, 2007, 105: 41

19 Nakajima K, Okamura M, Kondo J N, Domen K, Tatsumi T, Hayashi S, Hara M. Chem Mater, 2009, 21: 186

20 Suganuma S, Nakajima K, Kitano M, Kato H, Tamura A, Kondo H, Yanagawa S, Hayashi S, Hara M. Microporous Mesoporous Mater, 2011, 143: 443

21 Ryoo R, Joo S H, Jun S. J Phys Chem B, 1999, 103: 7743

22 Van Der Voort P, Ravikovitch P I, De Jong K P, Neimark A V, Janssen A H, Benjelloun M, Van Bavel E, Cool P, Weckhuysen B M, Vansant E F. Chem Commun, 2002: 1010

23 Wang Y, Liu Y M, Li X H, Wu H H, He M Y, Wu P. J Catal, 2009, 266: 258

24 Furuta S, Matsuhashi H, Arata K. Catal Commun, 2004, 5: 721

25 Zong M H, Duan Z Q, Lou W Y, Smith T J, Wu H. Green Chem, 2007, 9: 434 